\title{
ДО ПИТАННЯ ПРО ЛІТЕРАТУРОЗНАВЧУ ПРОПЕДЕВТИКУ ЖАНРУ ПРИТЧІ В ПОЧАТКОВІЙ ШКОЛІ
}

\begin{abstract}
Анотація. Статтю присвячено методичним проблемам вивчення притчі у початковій школі. Окреслено ґенезу жанру, обгрунтовано його актуальність та виховний потенціал. Зосереджено увагу на проблемі термінотворення та фрормлюваннях визначення жанру притчі в підручниках з літературного читання для 4 класу за новою програмою (2015); проаналізовано запропоновані дефініції в контексті академічної літературознавчої традищії, визначено вектори літературознавчої пропедевтики, закладеної у дефініції притчі В. Науменко, О. Савченко та М. Чумарної. Систематизовано та узагальнено спільні й відмінні ознаки притчі, актуалізовані у поданих визначеннях. Окрему увагу приділено оглядовій характеристиці художніх текстів притч в аналізованих підручниках, осмислено принципи їх відбору та ступінь відповідності авторським визначенням жанру.
\end{abstract}

Ключові слова: дефініція, дидактичність, жанр, літературна пропедевтика, літературне читання, мораль, притча.

Dymovska Anna Municipal establishment "Balta Pedagogical Professional College"

\section{ON LITERARY PROPAEDEUTICS OF PARABLE GENRE IN PRIMARY SCHOOL}

Summary. The article deals with methodical problems of formation of terms and study of parables in primary school. The genesis of the genre, which reaches folklore, as well as monuments of ancient Indian ("Panchatantra") and Jewish ("Bible") literatures is outlined, its features (lyric-epicism, didactic, philosophical orientation, moralism). The need to study art genres in the intercultural aspect is justified, as it allows not only to deepen knowledge about them, but to come closer to the universal, timeless and not only allows to deepen knowledge out them, but also to come closer to the universal and spaceless reception of literature, which begins in primary school. It was found that the implementation of literary propaedeutics in the appropriate way contributes to the formation of a thoughtful reader, resulting in a growing role of school methodological support in the study of the subject "Literary Reading". It is determined that comparative analysis of the terminological apparatus of various textbooks on literary reading, which would contribute to their improvement, is a topical vector of scientific inquiry. Literary propaedeutics of the parable requires reliance on a number of concepts that students must have an idea of in order to understand the difference of the new genre (the concept of folklore, the distinction between the prose and poetry, teaching/morality, etc.) from those studies in previous classes. In this regard, attention is focused on the wording of the definition of the genre of the parable in textbooks for reading for grade 4 according to the new program (2015); the proposed definitions in the context of the academic literary tradition are analyzed; the vectors of literary propaedeutics embedded in the definition of the parable by V. Naumenko, O. Savchenko and M. Chumarna are determined; the reasons of structural multiple-level system of the term are found out. The common and distinctive features of the parable, actualized in the given definitions, are systemized and generalized. Particular attention is paid to the review characteristics of literary texts of parables in the analyzed textbooks, the principles of their selection (aesthetic, folklore and synthetic) and the degree of compliance with the author's definitions of the genre. It is proved that the definitions of the analyzed genre in the textbooks correlate with the academic definition of a parable in Ukrainian literary criticism, correspond to the appropriate level of literary propaedeutics for 4-grade students and allow to form elementary ideas about a parable necessary for semantic and structural analysis of works.

Keywords: definition, didacticism, genre, literary propaedeutics, literary reading, moral, parable.

$\Pi$ ритча в колі дитячого читання репрезентує архаїчні жанри. Г. Бондаренко вважає, що «як літературно-мистецьке явище притча зароджується навіть не в біблійні, а в добіблійні часи» [2, с. 9]. Ю. Клим’юк пропонує таку схему виникнення притчі: від міфру до казки, від казки до аполога (казки про тварин), з якого розвинулися, на думку дослідника, притча і байка [5, с. 444]. Деякі дослідники виводять ґенезу притчі від пам'яток староіндійської ("Панчатантра», у перекладі - «П'ять кошиків житейської мудрості») та єврейської (Біблія) літератур [7, с. 560], при цьому М. Луцюк відзначає: «...Месія не був першим i єдиним біблійним персонажем, що користувався притчами, хоча сам жанр притчі перш за все пов'язаний у свідомості європейця, а тим більше християнина, 3 Iсусом Христом»
[8, с. 531]. Уже в межах Біблії простежуеться динаміка притчі від Соломонових текстів прикладного, побутового спрямування до більш узагальнених теологічно-фрілософрських зразків притчі в проповіді Христа [2, с. 10]. Можливо, саме приналежністю до текстів сакрального значення можна пояснити актуальність притчі як дидактичного жанру на різних етапах літературного процесу, а також їі вкорінення в навчально-виховних системах - як давніх, так і сучасних. За свідченням Л. Архипової, «література постае своєрідною скарбницею дивакуватості, непоміченої краси, зникаючої історії, видозміни та викривлення людського існування в сучасному мінливому світі» $[1$, с. 38]. Вивчення архаїчних жанрів, до яких відносять і притчу [10, с. 69], ілюструе це найбільш виразно. 
Постановка проблеми. Згідно з програмою предмету «Літературне читання», притчі вивчаються у 4 класі. Літературознавчий принцип визначення змісту літературного читання передбачае «уведення до системи підготовки дитини-читача літературознавчих понять, які засвоюються учнями практично, на рівні уявлень» [6]; до таких понять належать, зокрема, уявлення про жанрові особливості твору. У межах літературознавчої пропедевтики як змістової лінії програми чітко визначено, що учень 4 класу «розрізняе, визначае, обтрунтовуе вивчені раніше жанрові ознаки літературних творів, які опрацьовувалися під час навчання в 2-4 класах; (...) співвідносить літературний твір 3 його жанром» [6]. Одначе формування в учня таких навичок та компетентностей уможливлюеться, перш за все, за наявності чітких формулювань літературознавчих термінів у підручниках 3 «Літературного читання» (на необхідність з'ясування термінології вказуе, наприклад, Г. Волошина [3, с. 85]). Сучасне розмаїття підручників провокуе зіставлення використаного в них термінологічного апарату задля виявлення найбільш зрозумілих для школярів, адаптованих відповідно до їхніх вікових особливостей, логічно струнких визначень літературознавчих понять. Метою статті $є$ порівняння формулювань визначення жанру притчі в підручниках з літературного читання для 4 класу та визначення їхньої співвіднесеності з трактуваннями жанрових особливостей притчі в українському академічному літературознавстві.

Виокремлення нерозв'язаної частини проблеми. У добу постмодерного літературознавства особливої ваги набувають проблеми генологіï. Вивчення художніх жанрів у міжкультурному аспекті дозволяе не лише поглибити знання про них, а й наблизитися до універсальної, надчасової та позапросторової рецепції літератури, яка починаеться ще за шкільною партою. Здійснення літературознавчої пропедевтики у відповідному ключі сприяе формуванню вдумливого читача. Роль шкільного методичного забезпечення у цьому процесі надзвичайно важлива, а отже компаративний аналіз термінологічного апарату різних підручників з літературного читання, який сприяв би їхньому вдосконаленню, $є$ актуальним вектором наукових пошуків.

Аналіз останніх досліджень та публікацій. Вивченню генези та жанрової специфріки притчі, а також проблемам літературознавчої пропедевтики в школі присвячено праці дослідників С. Абрамовича, С. Аверинцева, Л. Берестовської, А. Близнюка, І. Богачевської, Г. Бондаренко, О. Бондаренко, Ю. Веремчук, Г. Волошиної, О. Галича, І. Голубченко, Т. Данилової, С. Добротворського, Л. Іванової, М. Ільїної, Т. Качак, Ю. Клим’юка, О. Колодій, Т. Котик, Р. Кузьміної, Л. Кушнарьової, Ю. Левіна, М. Луцюка, В. Мартиненко, С. Мельникової, О. Митник, В. Пахаренка, Л. Піхтовнікової, Н. Прокоф'єва, В. Сиротенка, А. Ситченкка, М. Собуцького, Ю. Султанова, А. Ткаченка, О. Товстенко, Л. Туріщевої, В. Тюпи, Н. Хамської, Л. Цимбалюк, С. Щербини, В. Якименко та ін.

Для порівняльного аналізу було обрано підручники 3 літературного читання авторів Науменко В.О. (2015), Савченко О.Я. (2015), Чумарної M.I. (2015).
Виклад основного матеріалу. Присутність притч у давньоруських пам'ятках дидактичного спрямування («Ізборник» Святослава, давньоукраїнська редакція візантійської «Пчели»), у бароковій культурі (зокрема, у творчості Г. Сковороди), актуалізація цього жанру у збірці І. Франка "Мій Ізмарагд», пізніше - у творах В. Барки та В. Шевчука дає підстави говорити про трансформацію жанру та засвідчуе його виховний потенціал. На думку Н. Хамської, вивчення притч у літературних шкільних курсах «забезпечуе формування ціннісних життевих оріентирів (...), ціннісного ставлення до інших», «активізуе інтерес до процесу набуття морального досвіду», формуе «здатність дотримуватись етичних норм у повсякденному житті» [13, с. 180]. Позатим, жанр притчі невипадково запропоновано до вивчення у 4 класі - філософрське та моралізаторське спрямування роблять його складнішим для сприйняття, ніж, наприклад, споріднений жанр байки. Літературознавча пропедевтика притчі вимагае опертя на ряд понять, про які учні повинні мати сформоване уявлення, щоб зрозуміти, у чому ж полягае відмінність нового жанру (поняття фольклору, розрізнення прозових та віршованих текстів, повчальність / мораль тощо). Тяглість літературної традиції притчі, іï міжродова природа, відзначена багатьма дослідниками (А. Ткаченко, відзначаючи тяжіння притчі до «чистоти роду», зауважуе ії «ліро-епізацію»: «й умоглядний холод може розтопити сильна поетична пристрасть» $[12$, с. 128]), проблемність та дидактичність - усе це зумовлюе структурну багаторівневість дефініції, яка, до того ж, мае бути зрозумілою для учнів 4 класу (9-10 років).

Порівняймо запропоновані в різних підручниках з літературного читання визначення притчі та зразки художніх текстів, представлені для ознайомлення з новим жанром (див. таблицю 1).

Як бачимо, у всіх запропонованих дефініціях притчі акцентовано дидактичність жанру, а також вказано на невеликий обсяг. Решта перелічених ознак відмінна у різних авторів-укладачів. Так, В. Науменко у визначенні притчі звертае увагу на ії витоки; це визначення корелюе з дефініціею О. Галича: «притча - короткий фольклорний або літературний твір повчального характеру, оріентований переважно на алегоричну форму доведення змісту етичних цінностей буття» $[4$, c. 281]. Заувага про урочистий характер оповіді, яка зустрічається тільки у В. Науменко, стосуеться форми твору і може вважатися літературознавчою пропедевтикою таких понять, як пафос та патетичність. 3 огляду на окреслення фольклорного походження жанру притчі, незначним недоліком підручника В. Науменко може видатися відсутність серед запропонованих текстів зразків народних притч.

У дефініції О. Савченко здійснено літературознавчу пропедевтику поняття ідеї як складника змісту твору, про що свідчить настанова на перемогу добра та справедливості. Через акцент на подієвості («якась життева пригода») актуалізуеться також фабульність жанру притчі, специфіка якої полягае в тому, що «до наперед заданої ідеї підбираються події» [5, с. 444]. Загальна стрункість визначення у підручнику О. Савченко, його відповідність до академічних дефініцій 
Таблиця 1

\begin{tabular}{|c|c|c|}
\hline Підручник & Дефініція притчі & Запропоновані художні тексти \\
\hline $\begin{array}{l}\text { Науменко В.О. Літературне } \\
\text { читання: укр. мова для } \\
\text { загальноосвіт. навч. закл. : підруч. } \\
\text { для 4-го кл. загальноосвіт. навч. } \\
\text { закл. Київ : Генеза, 2015. } 176 \text { с. } \\
\end{array}$ & $\begin{array}{l}\text { Притча - «короткий фольклорний } \\
\text { або літературний твір повчального } \\
\text { характеру. Для притчі властивий } \\
\text { урочистий характер оповіді» } \\
{[9, \text { с. } 18] .} \\
\end{array}$ & $\begin{array}{l}\text { Л. да Вінчі «Лебідь» (літературна } \\
\text { притча). }\end{array}$ \\
\hline $\begin{array}{l}\text { Савченко О.Я. Літературне } \\
\text { читання : підруч. для 4-го кл. } \\
\text { загальноосвіт. навч. закл. } \\
\text { Київ : Видавничий дім «Освіта», } \\
\text { 2015. } 192 \text { с. } \\
\end{array}$ & $\begin{array}{l}\text { Притча - «невелике усне } \\
\text { оповідання повчального характеру } \\
\text { про якусь життеву пригоду. } \\
\text { Вона утверджує перемогу добра, } \\
\text { справедливості» [11, с. 12]. } \\
\end{array}$ & $\begin{array}{l}\text { «Без труда нема плода» (народна } \\
\text { притча); } \\
\text { «У пригоді» (народна притча; } \\
\text { записала Олена Пчілка). }\end{array}$ \\
\hline $\begin{array}{l}\text { Чумарна М.І. Літературне } \\
\text { читання : Українська мова : } \\
\text { підручник для } 4 \text { кл. загальноосвіт. } \\
\text { навч. закл. Тернопіль : Навчальна } \\
\text { книга - Богдан, 2015. } 208 \text { с. }\end{array}$ & $\begin{array}{l}\text { Притчі - «короткі повчальні } \\
\text { життеві історії» [14, с. 8]; «короткі } \\
\text { життєві історї̈, в яких яскраво } \\
\text { виражена одна повчальна думка» } \\
{[14, \text { с. 40]. }}\end{array}$ & $\begin{array}{l}\text { «Сила слова», «Корінь і стебло», } \\
\text { «Треба нахилитися» (народні притчі); } \\
\text { «Про самарянина» (Свангельська } \\
\text { притча); } \\
\text { Г. Сковорода «Годинникові колеса» } \\
\text { (літературна притча). }\end{array}$ \\
\hline
\end{tabular}

частково нівелюеться формулюванням «усне оповідання»: усе-таки, більшість дослідників визначають притчу не лише як фольклорний, а й літературний твір; біблійні притчі мають цілком конкретних авторів - Соломона або Ісуса Христа. Утім, автор-укладач урівноважуе цю неточність тим, що пропонує для вивчення у 4 класі тільки народні притчі.

Акцент на подієвості притчі робить також М. Чумарна. У цілому ї̈ дефініція найбільш загальна: окрім дидактичності жанру, у ній не названо жодної іншої ознаки, яка б посутньо вирізняла притчу з-поміж жанрів, відомих учням 4 класу. Зате, на противагу решті аналізованих підручників, авторка пропонуе найбільш розмаїту добірку притч, серед яких $є$ і народні, і біблійні (новозавітні), і літературні тексти. Варто відзначити також те, що в підручнику М. Чумарної вивчення притч не зведено до окремого блоку - відповідно до композиції підручника, учні вперше вивчають новий жанр на початку навчального року, а в другому семестрі мають нагоду актуалізувати та поглибити попередньо сформовані уявлення про притчу, розширити коло читання.

Заслуговуе на окрему увагу питання про розрізнення в 4 класі притчі та байки, адже обидва жанри примітні дидактичністю, моралізаторством, утвердженням ідеї торжества добра та справедливості. В аналізованих підручниках основною диференційною ознакою виступає прозова форма для притчі та здебільшого віршована - для байки, хоча такий принцип не може вважатися задовільним з точки зору академічного літературознавства, адже, наприклад, байки Г. Сковороди написано в прозовій формі. Звісно, з попередніх класів учням відомо, що байку як жанр вирізняе система персонажів-тварин, в образах яких репрезентовано людські якості та риси характеру. 3 метою уникнення плутанини та формування більш конкретних уявлень про жанри, варто наголошувати на цьому під час вивчення притч.
Висновки та пропозиції. Багатовекторність підходів до формулювання дефініцій притчі, представлених у підручниках 3 літературного читання В. Науменко, О. Савченко та М. Чумарної, свідчить як про скомплікованість цього архаїчного жанру, так і про рішуче прагнення авторів зробити притчу зрозумілою для учнів 4 класу. 3 огляду на генезу та морально-етичну наснаженість жанру, у наш час це завдання не 3 легких. Оригінальність аналізованих авторських концепцій трактування притчі, поза дедініціями, проявилася, зокрема, у доборі текстів притч: так, В. Науменко зосередила увагу на літературній притчі зарубіжного автора, яка має, окрім виховного, виразне естетичне спрямування (естетичний принцип добору текстів); О. Савченко обрала традиційний шлях вивчення фрольклорних притч, національний код і мораль яких більш зрозумілі українським школярам (орієнтація на фольклор); М. Чумарна розширила коло читання, залучаючи тексти різного походження (синтетичний принцип - формування кола читання на базі різноманітних джерел), і якщо їхній кількісний вимір та обсяг можуть видатися обтяжливими для шкільної програми, то якісний показник цих текстів і можливість викликати з їх допомогою читацький інтерес не викликають сумнівів.

Дефініції притчі в аналізованих підручниках сфрормульовано з урахуванням пізнавальних можливостей дітей. Попри незначні суперечності, вони корелюють із академічним визначенням притчі в українському літературознавстві, відповідають належному рівневі літературознавчої пропедевтики для учнів 4 класу та дозволяють сформувати елементарні уявлення про новий жанр, необхідні для смислового та структурного аналізу творів. Вважаємо актуальними подальші дослідження заявленої проблематики в напрямі розрізнення жанрів байки та притчі в початковій школі.

\section{Список літератури:}

1. Архипова Л. Апологія мудрості літератури. Філособбська дулка. 2011. № 1. С. 37-48.

2. Бондаренко Г.Ф. Літературознавчі проспекції: компаративістська генологія. Житомир : Вид-во «Полісся», 2014.240 с.

3. Волошина Г.П. Особливості уроків читання та літературознавча пропедевтика у початковій школі : Посіб. для студентів та учителів почат. кл. Умань, 2011. 126 с.

4. Галич О., Назарець В., Васильєв Є. Теорія літератури : Підручник / За наук. ред. Олександра Галича. 4-те вид., стереотип. Київ : Либідь, 2008. 488 с. 
5. Лексикон загального та порівняльного літературознавства [Текст] / голова ред. А. Волков ; Буковинський центр гуманітарних досліджень. Чернівці : Золоті литаври, 2001. $634 \mathrm{c.}$

6. Літературне читання. Навчальна програма для загальноосвітніх навчальних закладів. 2-4 класи. URL: https://mon.gov.ua/storage/app/media/zagalna\%20serednya/programy-1-4-klas/2.-literaturne-chitannya.2-4-klas-29.07-tanya.docx

7. Літературознавчий словник-довідник / За ред. Р.Т. Гром’яка, Ю.І. Коваліва, В.І. Теремка. Київ : ВЦ «Академія», 2007. 752 c.

8. Луцюк М.В. Старозавітна повістева притча: історико-літературний контекст. Актуальні проблели слов'янської фбілологї : Міжвузівський збірник наукових статей. Київ - Ніжин : Аспект-Поліграф, 2006. Вип. XI: Лінгвістика і літературознавство. Частина II. С. 531-538.

9. Науменко В.О. Літературне читання: укр. мова для загальноосвіт. навч. закл. : підруч. для 4-го кл. загальноосвіт. навч. закл. Київ : Генеза, 2015. 176 с.

10. Пахаренко B.I. Основи теорії літератури. Київ : Генеза, 2009. 296 с.

11. Савченко О.Я. Літературне читання: підруч. для 4-го кл. загальноосвіт. навч. закл. Київ : Видавничий дім «Освіта", 2015. 192 с.

12. Ткаченко А.О. Мистецтво слова: Вступ до літературознавства : Підручник для студентів гуманітарних спеціальностей вищих навчальних закладів / 2-е вид., випр. і доповн. Київ : ВПЦ «Київський університет», 2003. 448 с.

13. Хамська Н. Формування моральних якостей майбутнього вчителя засобами притч. Педагогічний дискурс. 2016. Вип. 21. С. 174-181.

14. Чумарна M.I. Літературне читання : Українська мова : підручник для 4 кл. загальноосвіт. навч. закл. Тернопіль : Навчальна книга - Богдан, 2015. 208 с.

\section{References:}

1. Arkhypova L. (2011) Apolohiia mudrosti literatury [Apology of the wisdom of literature]. Philosophical thought, no. 1, pp. 37-48. (in Ukrainian)

2. Bondarenko H.Ph. (2014) Literaturoznavchi prospektsii: komparatyvistska henolohiia [Literary prospects: comparative genealogy]. Zhytomyr: Polissia. (in Ukrainian)

3. Voloshyna H.P. (2011) Osoblyvosti urokiv chytannia ta literaturoznavcha propedevtyka u pochatkoviii shkoli: Posibnyk dlia studentiv ta uchyteliv pochat. $\mathrm{kl}$. [Peculiarities of reading lessons and literary propaedeutics in primary school. Textbook for students and primary school teachers]. Uman. (in Ukrainian)

4. Halych O., Nazarets V., Vasyliev Ye. (2008) Teoriia literatury: Pidruchnyk [Theory of literature: a textbook]. Kyiv: Lybid. (in Ukrainian)

5. Volkov A. (2001) Leksykon zahalnoho ta porivnialnoho literaturoznavstva [Lexicon of general and comparative literature]. Bukovyna center of humane studies. Chernivtsi: Zoloti Lytavry. (in Ukrainian)

6. Literaturne chytannia. Navchalna prohrama dlia zahalnoosvitnikh navchalnykh zakladiv. 2-4 klasy [Literary reading. Curriculum for secondary schools. Grades 2-4]. Available at: https://mon.gov.ua/storage/app/media/zagalna\%20 serednya/programy-1-4-klas/2.-literaturne-chitannya.-2-4-klas-29.07-tanya.docx (accessed 26 February 2021).

7. Hromiak R.T., Kovaliv Yu.I., Teremok V.I. (2007) Literaturoznavchyi slovnyk-dovidnyk [Literary dictionaryreference book]. Kyiv: Akademiia. (in Ukrainian)

8. Lutsiuk M.V. (2006) Starozavitna povisteva prytcha: istoryko-literaturnyi kontekst [Old Testament parable: historical and literary context]. Current topics of Slavic pholology: Inter-university collection of scientific articles, vol. 11: Linguistics and literary studies, part II, pp. 531-538. (in Ukrainian)

9. Naumenko V.O. (2015) Literaturne chytannia: ukr. mova dlia zahalnoosvit. navch. zakl.: pidruch. dlia 4-ho kl. zahalnoosvit. navch. zakl. [Literary reading: Ukrainian language for secondary educational establishments: textbook for grade 4 of a secondary school]. Kyiv: Heneza. (in Ukrainian)

10. Pakharenko V.I. (2009) Osnovy teorii literatury [Fundamentals of literary theory]. Kyiv: Heneza. (in Ukrainian)

11. Savchenko O.Ya. (2015) Literaturne chytannia: pidruch. dlia 4-ho kl. zahalnoosvit. navch. zakl. [Literary reading: textbook for grade 4 of a secondary school]. Kyiv: Osvita. (in Ukrainian)

12. Tkachenko A.O. (2003) Mystetstvo slova: Vstup do literaturoznavstva: Pidruchnyk dlia studentiv humanitarnykh spetsialnostei vyshchykh navchalnykh zakladiv [The Art of the Word: Introduction to Literary Studies: a textbook for Humanities students in higher education]. (2 ${ }^{\text {nd }}$ ed., rev.). Kyiv: Kyivskyi universytet. (in Ukrainian)

13. Khamska N. (2016) Formuvannia moralnykh yakostei maibutnoho vchytelia zasobamy prytch [Formation of moral qualities of the future teacher by means of parables]. Pedagogical discourse, vol. 21, pp. 174-181. (in Ukrainian)

14. Chumarna M.I. (2015) Literaturne chytannia: Ukrainska mova: pidruchnyk dlia 4 kl. zahalnoosvit. navch. zakl. [Literary reading : Ukrainian language : textbook for grade 4 of secondary school]. Ternopil: Navchalna knyha Bohdan. (in Ukrainian) 